\title{
Ortopedi ve Travmatolojide bilirkişilik
}

\section{Legal expertise in orthopedics and traumatology}

\author{
Mücahit Görgeç
}

Ortopedi ve Travmatoloji Uzmanı, Serbest

\begin{abstract}
Bir Ortopedi ve Travmatoloji uzmanı adli makamlar tarafından görevlendirildiği zaman, geçerli bir mazeret bildirmedikçe, bilirkişilik yapmak zorundadır. Bilirkişilik yapabilmek için, öncelikle Adalet Bakanlığının yetkilendirdiği kurumların (yetkili kurum, Türk Tabipleri Birliği'dir) açtığı kurslara katılıp sertifika sahibi olmak ve "bilirkişilik bölge kurulları"na kayıt yaptırmak gerekir. Ama kişi, kaydı olmadan da adli makamlar tarafından bilirkişi olarak görevlendirilebilir. Bu görev ifa edilirken, Resmi Gazetenin 03.08.2017/30143 sayısında yayımlanan "bilirkişi yönetmeliği” okunmalı ve kılavuz edinilmeli, önceki örneklerden yararlanılmalıdır.
\end{abstract}

Anahtar sözcükler: ortopedi; bilirkişilik; yönetmelik; bilirkişi raporu

\begin{abstract}
For an orthopedics and traumatology specialist, it is a duty to be a legal expert unless he/she reports a valid excuse. In order to be an expert, first of all, it is necessary to attend the courses opened by the institutions authorized by the Ministry of Justice (the authorized institution is the Turkish Medical Association) and to have a certificate, and to register for the "regional councils of experts". However, the person can be appointed as an expert by the judicial authorities without registration. In carrying out this task, the "expert regulations" published in the Official Gazette No. 03.08.2017 / 30143 should be read and taken as a guide, and the previous examples should be referred.
\end{abstract}

Key words: orthopedics; legal expertise; regulations; expert report

göre, her bölge adliye mahkemesinin kurulu bulunduğu yerde "bilirkişilik bölge kurulları" oluşturulur. Madde 21/b'ye göre, bölge kurulları her yıl belirli bir tarihe (15 Ekim) kadar bilirkişi olmak isteyenlerin başvurusunu alır, bilirkişiliğe kabule, bilirkişilerin sicile ve listeye kaydedilmesine karar verir ve listeler oluşturur. Madde 30'a göre, bilirkişilerin eğitim alma zorunluluğu vardır ve şekli belirlenmiştir; üç yılda bir "yenileme eğitimi"ne de katılma zorunluluğu vardır. Madde 33'e göre, eğitim veren yetkili kuruluşlardan biri de Türk Tabipleri Birliğidir. Madde 38, bilirkişiliğe başvuru ve kabul şartlarını içerir. Madde 44'e göre, bilirkişiliğe kabul edilenlerin yemin etmesi gerekmektedir. Madde 45'e göre bilirkişilere bir sicil numarası verilir. Madde 50/1'e göre, bilirkişi, resen veya talep üzerine ilgili makam tarafından görevlendirilebilir. 50/2'ye göre, bilirkişiler bölge kurullarınca düzenlenen listelerden seçilir. İşin mahiyetine göre, gerekçesi açıkça gösterilmek kaydıyla, birden fazla bilirkişi görevlendirilebilir. 50/4'e göre, Bölge

- Illetişim adresi: Prof. Dr. Mücahit Görgeç, Hasırcıbaşı Cad. Birlik Apt. 22/4 Kadıköy, İstanbul

Tel: 0542 - 23456 66, 0216 - 3362555 e-posta: mucahitgorgec@gmail.com

- Geliș tarihi: 9 Ekim 2019 Kabul tarihi: 11 Kasım 2019 
Kurulunun hazırladığı listede bilgisine başvurulacak uzmanlık alanında bilirkişi bulunmaması hâlinde, diğer bölge kurullarının listelerinden, burada da bulunmaması halinde listelerin dışından bilirkişiliğe kabul şartlarını haiz kişiler arasından görevlendirme yapılabilir. Listelerin dışından görevlendirilen bilirkişiler, bölge kuruluna bildirilir. Liste dışından görevlendirilen bilirkişinin, bilirkişilik yapma şartlarını taşımadığının bölge kurulu tarafından tespiti halinde, bu kişi UYAP'a (Ulusal Yargı Ağı Bilişsim Sistemi) kaydedilmez ve durum görevlendirmeyi yapan makama bildirilir. Madde 51/1'e göre, görevlendirilen bilirkişiye, inceleme yaptırılacak konunun kapsamı ve sınırları yazılı olarak bildirilir ve açıkça anlatılır.

Bu yazıda;

a) İnceleme konusunun bütün sınırlarıyla ve açıkça belirlenmesi

b) Bilirkişinin cevaplaması gereken sorular

c) Takdir edilen bilirkişi ücreti

ç) Raporun verilme süresi

d) Gerçeğe aykırı mütalaada bulunması halinde 26/9/2004 tarihli ve 5237 sayılı Türk Ceza Kanununun 276 'ncı maddesi uyarınca cezalandırılacağı hususlarına yer verilir. ${ }^{[2]}$

Madde 52'nin fıkralarında, bilirkişinin görevlendirmeyi yapan makam tarafından verilen süre içinde raporunu hazırlayarak sunmakla yükümlü olduğu, bunun için ek süre isteyebileceği, raporunu tamamlamadığı zaman da karşılaşacağı yaptırımlar yazılıdır. Bilirkişi tayin edilen kimse, madde 53/1'e göre, kendisine verilen görevin, uzmanlığı, özel veya teknik bilgiyi gerektirmediğini, temel ve alt uzmanlık alanına girmediğini, inceleme konusu iş ve işlemlerin açıklığa kavuşturulması için alanında uzman başka bir bilirkişi ile işbirliğine ihtiyaç duyduğunu veya varsa görevden çekinmeyi haklı kılacak bir mazeretinin bulunduğunu ileri sürerek görevin kendisine verilme tarihinden veya çekinmeyi gerektirecek durumun sonradan öğrenilmesi halinde bu tarihten itibaren en geç bir hafta içinde görevlendirmeyi yapan makama görevden çekileceğini bildirir. Madde 54, bilirkişinin yetki alanını belirlemiştir. Buna göre; bilirkişi, yapacağı ön incelemede, incelemeyi gerçekleştirebilmesi için bazı hususların önceden araştırılması ve tespiti ile kendisine teslim edilen dosya ve belgelere ilave olarak başka kayıt ve belgelere ihtiyaç duyması halinde bir hafta içinde görevlendirmeyi yapan makamdan talepte bulunur ve görev alanı veya sınırları hakkında tereddüde düşerse, görevlendirmeyi yapan makamdan bunun giderilmesini her zaman talep edebilir. Madde 55'te, bilirkişi raporunda yer alması gereken hususlar maddeler halinde sıralanmıştır. Madde 56, ilgili mahkemenin bilirkişi raporunu değerlendirmesi hususuna değinir, buna göre, görevlendirmeyi yapan makam, bilirkişi raporundaki eksiklik yahut belirsizliğin tamamlanması veya açıklığa kavuşturulmasını sağlamak için, bilirkişiden, yeni sorular yöneltmek suretiyle ek rapor isteyebilir. Bilirkişi raporunda eksik veya anlaşılmaz hususların bulunması halinde; görevlendirmeyi yapan makam tarafından belirlenen süre içinde bilirkişiden yazılı açıklama istenir. İhtiyaç duyulduğu takdirde, bilirkişinin oy ve görüşünü sözlü olarak açıklamasına karar verilirse, açıklamaları tutanağa geçirilir ve bilirkişinin de imzası alınır. Kurul hâlinde görevlendirme söz konusu ise, bilirkişilerin bilgilerine başvurulan hususu hemen aralarında müzakere etmelerine imkân tanınır ve müzakere sonucunda açıklanan oy ve görüş, tutanağa geçirilerek bilirkişilere imza ettirilir. Madde 58 , bilirkişinin cezai ve hukuki sorumluluğunu hatırlatır. Buna göre; bilirkişi, Türk Ceza Kanunu anlamında kamu görevlisidir, kasten gerçeğe aykırı mütalaada bulunması halinde, Türk Ceza Kanununun 276'ncı maddesi uyarınca sorumlu tutulur. Bilirkişinin kasten veya ağır ihmal suretiyle düzenlemiş olduğu gerçeğe aykırı raporun, hükme esas alınması nedeniyle zarar görmüş olanlar, bu zararın tazmini için Devlete karşı tazminat davası açabilirler. Devlet, ödediği tazminatı sorumlu bilirkişiye rücu eder.

\section{BIR ORTOPEDI VE TRAVMATOLOJI UZMANI BíLiRKIŞi DONANIMINI NASIL ELDE EDER?}

Bunun için, Adalet Bakanlığı tarafından yetkilendirilen kuruluşlara başvurarak "bilirkişi sertifika programı"na katılmalı ve sertifika almalıdır. Yukarıda zikredilen ilgili yönetmelik ve kanunları bilmelidir. Bunlardan ayrı olarak, Adalet Bakanlığı sitesinden ulaşılabilen ve sertifika programlarında okutulan temel eğitim kaynak ${ }^{[3]}$ ve katılımcı ${ }^{[4]}$ kitaplarını okumalıdır.

Temel eğitim katılımcı kitabında bilgiler soru-cevap şeklinde düzenlenmiştir. Bazı soru ve cevapları son derece öğreticidir ${ }^{[3]}$ :

Soru: Bilirkişi, davanın tarafları ya da üçüncü kişilerin bilgisine başvurabilir mi?

Cevap: Hukuk yargısı bakımından, bilirkişi incelemesini gerçekleştirirken ihtiyaç duyarsa, mahkemenin de uygun bulması kaydıyla tarafların bilgisine başvurabilir. Bilirkişinin hâkim gibi, tanık beyanlarının değerini değerlendirme yetkisi yoktur. Burada tanıkların dinlenilmesi salt bilgilenme, bilirkişinin uyuşmazlık konusu hakkındaki teknik kanaatini güçlendirme amaçlıdır. Bilirkişi, raporunu dinlediği tanıkların beyanlarına dayandıramaz. Keşif ya da 
duruşma sırasında bilirkişi hangi soruları yöneltmek istediğini hâkime bildirir. Hâkim bunu serbestçe değerlendirdikten sonra sorunun yöneltilip yöneltilmeyeceğine karar verecektir.

Ceza yargısı bakımından da bilirkişi, ilk olarak gerekli olması hâlinde, mağdura, şüpheliye veya sanığa soru yöneltebilir. Bilirkişi, saydı̆̆ımız kişilere, mahkeme başkanı, hâkim veya Cumhuriyet savcısı aracilığ ile soru sorabilecektir. Ancak mahkeme başkanı, hâkim veya Cumhuriyet savcısının, bilirkişinin doğrudan soru sormasına da izin vermesi mümkündür. Bilirkişinin soru sorma yetkisi onun ifade alma veya sorgu yetkisine sahip olduğu anlamına gelmemektedir.

Soru: Bilirkişi ek dosya ya da belge isteyebilir mi?

Cevap: Bilirkişi, yapacă̆ı ön incelemede, incelemeyi gerçekleştirebilmesi için bazı hususların önceden araştırılması ve tespiti ile kendisine teslim edilen dosya ve belgelere ilave olarak başka kayıt ve belgelere ihtiyaç duyması halinde, bir hafta içinde görevlendirmeyi yapan merciden talepte bulunur.

Soru: Bilirkişi raporunun formatı nasıl olmalıdır?

Cevap: Bir bilirkişi raporunda yer alması gereken hususlar ve bunların içeriği şu şekildedir:

- Kapak sayfası: Bilirkişi raporunun, bir kapak sayfasıyla başlaması gerekmektedir. Bu kapak sayfasında şunlar yer alacaktır:

- Görevlendirmeyi yapan merci (örneğin, T. C. Ankara 6. Asliye Ceza Mahkemesi; T. C. İzmir 3. Asliye Ticaret Mahkemesi gibi. . .)

- Dosya numarası (örneğin, 2017/26 Esas)

- Yargilamanın taraflarına ait bilgiler

- Bilirkişinin adı soyadı, unvanı, sicil numarası; tüzel kişiyse, ticaret unvanı, kanuni temsilcisinin adı ve soyadı, tüzel kişi adına raporu tanzim eden gerçek kişinin adı ve soyadı ile sicil numarası

- Içindekiler: Bu kısımda bilirkişinin, raporun içeriğinde yer alan hususları sırası ile göstermesi ticaret unvanı, kanuni temsilcisinin adı ve soyadı, tüzel kişi adına raporu tanzim eden gerçek kişinin adı ve soyadı ile sicil numarası sırası ile göstermesi gerekir. İçindekiler kısmının raporda yer alan temel başlıkların tümünü içermesi gerekir.

- Görev tanımı: Burada bilirkişi ilk olarak kendisini görevlendiren merciye ve taraflar hakkındaki bilgilere bir kez daha işaret edecektir. Bunu takiben, hangi konuda, ne yapmak için görevlendirildiğinin açık şekilde gösterilmesi gerekmektedir. Buna göre bu kısımda incelemenin konusu ve bilirkişinin gözlemlemesi ve incelemesi istenen maddi unsurlara yer verilecektir. Bu hususlar, bilirkişinin görevlendirilmesine ilişkin kararda bilirkişiye yöneltilen sorular şeklinde somutlaşmaktadır. Iş̧te, bilirkişi de bu soruları, kendisine yöneltilen sırayla, tek tek belirtecektir. Bilirkişi bu hususları henüz baştan belirttiğinde, vakaların tespitinden veya bunların değerlendirilmesinden sonra, sonuçlarını soruları ile karşılaştırabilecektir. Bu yönüyle daha raporu teslim etmeden, öz denetimini gerçekleştirebilecektir.

- Bilirkişi raporundaki sonuçların dayandığı literatür, veriler ve diğer materyaller: Bilirkişi, görüşünü oluştururken yararlandı̆̆ı tüm kaynaklara işaret etmek durumundadır. Bu görev nedeniyle incelenen bir taşınır veya bir taşınmaz yahut temin edilen bir kayıt veya belge olabilir. Bunların ayrı ayrı gösterilmemesi, raporun hükme esas alınmaması sonucunu doğurabilir. Bilirkişi incelemesi sırasında bilimsel veya teknik kaynak ve görüşlerden yararlanmışsa, bu kaynak ve görüşleri, hangi nedenle bu kaynaklardan yararlandığı açıkça gösterilmelidir.

- Bilirkişinin yaptığı çalışmanın ve yöntemlerin ayrıntılı olarak belirtilmesi: Burada bilirkişinin inceleme yöntem ve usulünü açıklaması gerekmektedir. Örneğin; bilirkişi incelemesinin konusunu bir yazı veya imza oluşturmaktaysa, bu yazı veya imzanın incelenmesinde ya da tıbbi bir incelemede hangi yöntemlerin uygulandığı açıklanmalıdır. Bilirkişi, bu yöntemlerin teknik karşılı̆̆ını belirtebilir. Bununla birlikte, yöntemin içeriği ilgililerin anlayabileceği şekilde aktarılmalıdır. Bilirkişi ayrıca, incelemeyi belli bir yerde yaptıysa bunun zamanını, taraflar ya da üçüncü kişilerle iletişime geçtiyse bunun biçimini göstermelidir.

- Analiz: Bilirkişiye yöneltilen sorular ve sıra numarası altında bunlara verilen yanıtlar ve bu yanıtların gerekçeleri: Raporun maddi içeriği, bu başlık altında yer alır. Burada bilirkişi tarafindan kendisine yöneltilen sorular, bu sefer yanıtlarıly birlikte sunulacaktır. Bu zorunluluk bilirkişi raporunun denetimine yöneliktir. Bu sayede, tüm soruların yanıtlanıp yanıtlanmadığı, taraflar ve mahkeme tarafindan görülebilecektir. Bu başlık, aslında bir sonraki başlık olan "Sonuç" ile bir bütün teşkil eder. Analiz aşaması, bilirkişi incelemesinin konusunu oluşturan maddî vakalar ile bilirkişinin gözlem ve tespitlerini içerir. Öte yandan, görevlendirmenin konusunu oluşturmaktaysa, bu gözlem ve tespitlere ilişkin nitelendirme ve değerlendirmeler bu başlık altında yer alacaktır. Hemen akabinde, 
her bir soruya verilen yanıta bir sonuç şeklinde yer verilecektir. Bilirkişi her halükârda sunduğu raporu gerekçelendirmelidir. Aksi takdirde bilirkişi raporu, ne taraflar ve hâkim tarafindan anlaşılabilir, ne de onun inandırıcılı̆̆ından söz edilebilir. Diğer taraftan, bilirkişinin incelediği konu hakkında farklı bir takım bilimsel veya teknik görüşler bulunmaktaysa, bilirkişi bunlardan birini diğerine neden tercih ettiğini açıklamalıdır. Burada gerek görüşe dayanak yapılan gerek aksi yöndeki kaynaklar belirtilmelidir. Bilirkişi, değerlendirmede bulunurken ikilemde kaldiysa, bu durumu, temel etik kurallardan dürüst davranmanın bir gereği olarak görevlendiren merciye bildirmelidir.

- Sonuç: Bilirkişinin ulaştığı sonuç, bir önceki başlık olan "Analiz" ile bir bütün teșkil eder. Özellikle, bilirkişi incelemesinin konusunu, birden fazla maddi mesele meydana getirmekteyse, bu hususlar, farklı başlık ve paragraflar altında yer almalı, her biri için ulaşılan sonuç da mutlaka ayrı ayrı gösterilmelidir.

- Bilirkişilerin imzası: Bilirkişi, raporu düzenlediği tarihte imza eder. Öte yandan bilirkişi raporu birden fazla sayfadan oluşuyorsa tüm sayfalar imzalanmalı yahut ayırt edici şekilde paraf edilmelidir. Imzasız bir rapor, hiçbir surette mahkeme tarafindan dayanak alınamaz; imza edilmek üzere geri çevrilmesi gerekir. Bilirkişi raporu imza edildikten sonra, artık üzerinde bir değişiklik yapılmaması gerekir. Ancak, zaruri bir sebeple değişiklik yapıldıysa, bu tahrifat anlamına geleceğinden, bu değişikliğin sebebinin gösterilmesi ve değişiklik yapılan yerin de imza edilmesi gerekir.

- Karşı oy ve gerekçesi: Bilirkişi incelemesi amacıyla birden fazla bilirkişi görevlendirilmişse, bu bilirkişilerin inceleme konusu vakaları tespit ettikten sonra farklı sonuçlara ulaşmaları da pekâlâ mümkündür. Diğer bilirkişilerden farklı sonuca ulaşan bilirkişinin bu azınlık görüşü, raporun sonunda ayrıca belirtilir ve imza edilir. Öte yandan, azınlıkta kalan bilirkişinin oy ve görüşünü ayrı bir rapor hâlinde mahkemeye sunması mümkündür.

- Maddi unsurları belgeleyen ve sonuçların açıklanmasına yardımcı olan şema, kroki, fotoğraf, tablo vs.: Bilirkişi raporuna, incelemeye esas maddi unsurları belgeleyen ve sonuçların açıklanmasına yardımcı olan şema, harita, kroki, fotoğraf, tablo ile diğer kayit ve belgelerin de eklenmesi gerekir.

Soru: Bilirkişinin görevlendirilmesinden rapor yazımına ve teslimine kadar geçen sürede neler yapılır?

Cevap: Bu süreç aşağıdaki şekilde gösterilmektedir (Şekil 1). ${ }^{[3]}$

\section{BIR ORTOPEDI VE TRAVMATOLOJI UZMANI NASIL BILIRKIŞiLIK YAPAR?}

Hekimin yaptığı uygulamanın hukuka uygunluğu esastır ve ilgili mahkeme bazen hukuka uygunluğu da sorabilir. Tıbbi uygulamanın hukuka uygunluğunun üç şartı vardır: Bu şartlar;

1) Hekimin yaptığı uygulamada yeterliliğinin olması,

2) Uygulama hakkında hastayı aydınlatmış ve rızasını almış olması,

3) Uygulamanın tıp biliminin verilerine uygun ve zorunlu olmasıdır.

Hekim eğitimini almadığı, uzmanlık alanı içerisinde olmayan bir uygulamayı hastasını bilgilendirmeden, aydınlatmadan ve rızasını almadan yaparsa, bir de bu uygulama, tıp verilerine uygun olmayan ve zorunlu olmayan bir uygulama ise, hukuka aykırı bir eylemde bulunmuş olur. Hasta şifa bulmuş olsa bile şikâyet hakkını kullanıp, hekimi mahkûm ettirebilir. Genellikle hekimler taksirli suç kapsamında yargılanmakla birlikte, bu üç hususu yerine getirmemiş bir hekim, hukuka aykırı bir eylem nedeniyle, kasıt unsuru ileri sürülerek bile yargılanabilir.

Hekimin yaptığı tıbbi uygulama şifa ile sonuçlanmamış ve sonuçta hastada bir sakatlık veya ölüm husûle gelmiş ise; uygulamada hata, acemilik, ihmal gibi bir kusurun olup-olmadığı ve bu kusur ile sonuç arasında illiyet bağı kurulup-kurulamayacağı sorulur.

Bilirkişi bu soruya cevap verirken, Dünya Tabipler Birliğinin, 1992 yılı 44. Genel Kurulunda "Tıbbi Uygulama Hatası (Malpraktis)" kavramını;

"hekimin, tedavi sırasında standart uygulamayı yapmaması, beceri eksikliği veya hastaya uygun tedavi verememesi neticesi oluşan zarar"

şeklinde tanımladığını göz önüne alarak, somut olayı aşağıdaki şekilde irdeleyebilir:

1. Hukuka uygunluk şartları yerine getirilmiş midir?

2. Tıbbi uygulama ve takibi usulüne uygun yapılmış mıdır? Hastaya konan teşhis doğru mudur? Endikasyon doğru mudur? Yapılan tedavi tıbbi standartlara uygun mudur?

3. Ortaya çıkan olumsuz sonucun nedeni komplikasyon mu? Tibbi bir hata mı (malpraktis)?

4. Hastayı ölüme veya sakatlanmaya götüren süreç komplikasyon veya tıbbi hata ile mi başlamıştır? Araya giren başka faktörler var mıdır? Nasıl gelişmiş ve seyretmiştir?

5. Bu sürece hangi noktalarda müdahale edilseydi olumlu seyredebilir ve hasta hayatta kalır veya eski fonksiyonel hale dönebilirdi? 


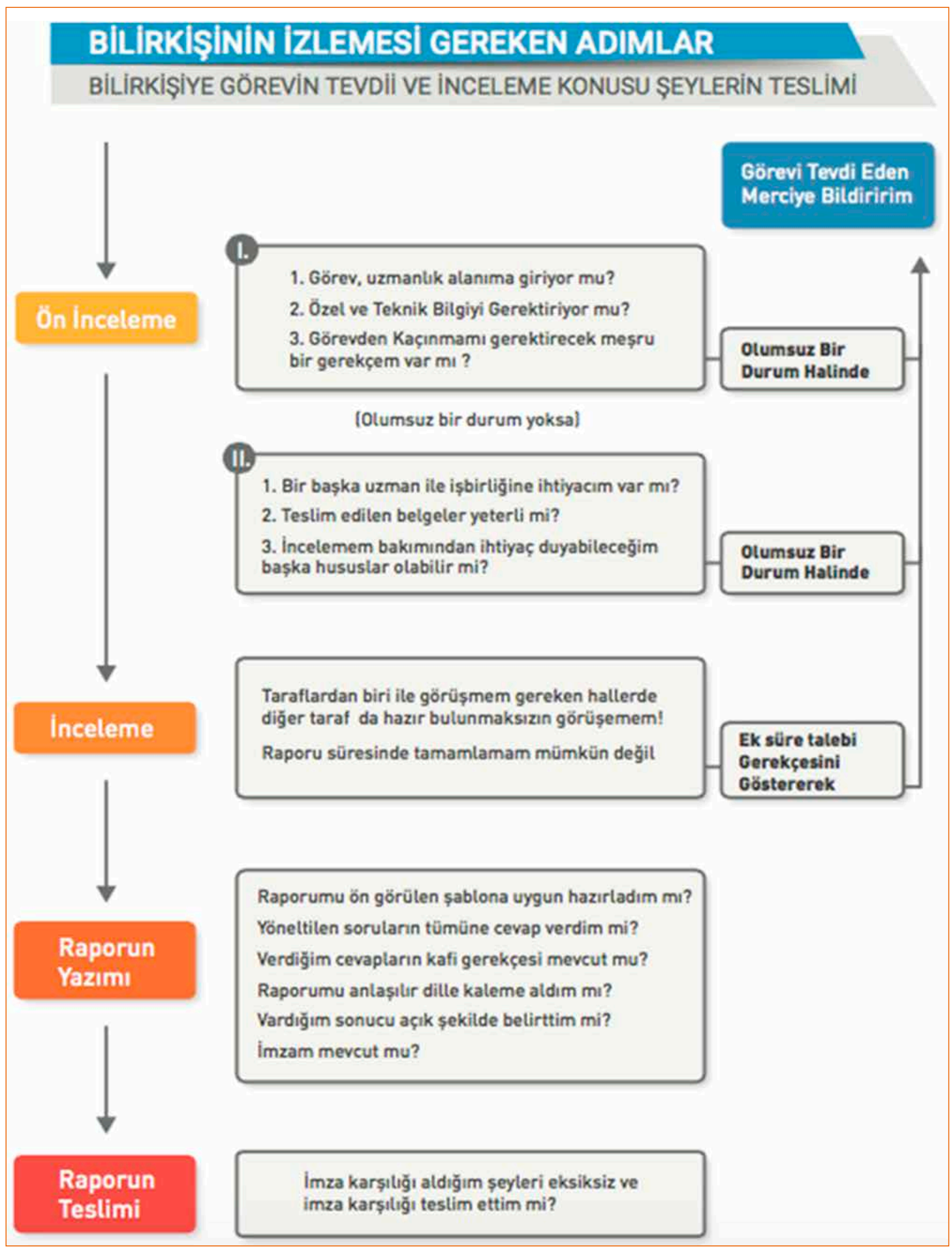

Şekil 1. Bilirkişinin izlemesi gereken adımlar. ${ }^{[3]}$ 
6. Yapılması gereken bu müdahale, yapılmamış mıdır?

7. "Süreç içerisinde yapılan hiçbir müdahale, gidişatı olumlu bir yöne sevk etmez ve hastanın hayatta kalmasına veya eski fonksiyonel hale dönmesine imkân vermezdi" denebilir mi? Yani, "Süreç ile sonuç arasında illiyet bağı kurulamaz" denebilir mi?

TOTBID'in Sağlık Hukuku Komisyonu olarak, bu başlıklara dikkat ederek tıbbi görüşümüzü yazmaktayız. Aşağıda örnek bir rapor, yer ve kişi isimleri ve tarihler çıkarılarak kopyalanmıştır.

\section{DOSYA INCELEMESI}

\section{A. Tarafımıza Sunulan Belgeler}

... 2. Asliye Ceza Mahkemesi'nin ... esas sayılı ceza dava dosyası sureti tarafımıza sunulmuştur. Dilekçeler, duruşma tutanakları ve sair yazışma müzekkereleri yanında;

- Devlet Hastanesi sayılı ve tarihli epikriz ve tıbbi kayıtları.

- ... Üniversitesi Sağlık Uygulama ve Araştırma Merkezi Plastik ve Rekonstrüktif Cerrahi Anabilim Dalı, ... tarihli epikriz, Ortopedi ve Travmotoloji Anabilim Dalı giriş-çıkış tarihli epikrizleri,

- ... Valiliği il İdare Kurulu tarafından başlatılan incelemeye istinaden ... tarihli üst yazı ile ibraz edilen Uzm. Dr. ... tarafından düzenlenen ... tarihli Ön İnceleme Raporu ve ilgili raporda atıf yapılan Dr. ... tarafından tanzim edilen ... tarihli Bilirkişi Raporu.

- ... Kaymakamlı̆̆ı'nın konunun Savcılık açısından soruşturma gerektirecek nitelikte olduğu kanaati ile Dr. ... hakkında verilen, ... tarihli "soruşturma izni verilmesi" kararı.

- Adli Tip Kurumu 2. Ihtisas Kurulu'nun, ... tarih, 6181 sayılı mütalaası.

- Cumhuriyet Başsavcılığı'nın ... numaralı iddianamesi.

- Adli Tıp Kurumu ... Adli Tıp Şubesi'nin ... karar sayılı raporu.

- Adli Tıp Kurumu Genel Kurulu'nun ... karar sayılı raporu.

\section{B. Dosyanın Özeti}

... isimli hasta traktöre kütük yüklerken sağ ayağına kütük düşmesinden üç gün sonra ... Devlet Hastanesi Acil Bölümüne başvurmuş, çekilen film sonrası Ortopedi ve Travmatoloji polikliniğine başvurması belirtilmiştir.

Hasta ... tarihinde aynı hastanenin Ortopedi ve Travmatoloji polikliniğine başvurmuştur. Hastanın Dr. ... tarafindan yapılan muayenesi ve tetkikleri sonucunda yumuşak doku travması teşhisi ile alçı atel yapılmıştır. Şişliğin inmesi için anti-infalamatuvar tedavi uygulanmıştır.
Kayıtlarda, acilde kısa bacak atel yapıldığı, poliklinik kaydında ise uzun kol-bacak alçı yapıldığı belirtilmiştir.

Aradaki çelişki, Dr. ... tarafından açıklanarak, kendisi hastaya kısa bacak atel yaptığını ve kayıtların sehven yazıldığını belirtmiştir.

Hasta sonrasında ... tarihinde ağrı şikayeti ile Dr. ... başvurmuş, yaraya debridman ameliyatı yapılmış, yeniden filmi çekilmesi istenmiştir. Hasta filmi çektirmemiş, ertesi gün, bu defa ayağında yumuşak doku bozukluğu, ayak bileği ve ayakta morluk, şişlik, soğukluk bulguları ile başvurmuştur.

Tekrar alçı atel uygulaması yapılarak, hasta ... Üniversitesi Sağlık Uygulama ve Araştırma Merkezine yönlendirilmiştir. Hasta, ... Üniversitesi Sağlık Uygulama ve Araştırma Merkezine ... tarihinde başvurmuştur.

Hastanın, ilgili üniversite hastanesinde Tip 2 Diabetes Mellitus (DM) hastası olarak kötü kokulu akıntılı yaraya yapılan tedavisinde, ... tarihinde bacağının kesilmesine karar verilmiştir. Hasta ilgili hastanede ... tarihine kadar tedavi görmüş, taburculuk sonrası kontrollerinde tekrar ameliyat gerekliliği saptanmış, ... tarihinde ikinci, ... tarihinde ise üçüncü ameliyatını olmuştur.

Hastanın, uzuv kaybı nedeniyle ... Kaymakamlığı'nın soruşturma izni sonrası, Adli Tıp Kurumu 2. Ihtisas Kurulu'nun ... tarih ... sayılı mütalaasına atıf yapılarak, ... Cumhuriyet Başsavcılığı'nın ... soruşturma numaraIı ... iddianame numaralı iddianamesi ile "Taksirle Bir Kişinin Yaralanmasına Neden Olma Suçu"nun oluştuğu iddialarıla ... 2. Asliye Ceza Mahkemesi'nin ... Esas sayılı ceza yargılama süreci başlatılmıştır.

\section{Tartışma}

Tarafımıza sunulan belgeler dikkate alınarak tarafımızdan inceleme talep edilen husus, sağlık hukuku boyutunda hasta ...'ya verilen sağı ı hizmeti ve hekimin ceza sorumluluğunun irdelenmesidir.

Somut olayda, Op. Dr. ...'nın iddianame ile cezalandırılmasının talep edildiği suç, Türk Ceza Kanunu Madde 89'da düzenlenen "taksirle bir kişinin yaralanmasına sebep olma" suçudur. Hasta yararına mesleki faaliyetini yerine getiren hekimin bu suçun faili olabilmesi için, suçun unsurlarının failin "gerekli dikkat ve özen yükümlülügüune” aykırılığı nedeniyle ortaya çıkması gerekmektedir. Dikkat ve özen yükümlülüğünün tespiti ise, ceza yargılaması kapsamında, her somut olaydaki nesnel koşullara göre yapılmalıdır.

Somut olayda hasta ...'nın sağ bacağını kaybetmesi hususunda Dr. ...'nın kusur içeren etkili bir eylemi olup olmadığının tespiti için, iddia edilen suçun unsurlarını belirlemek, eylem ile sonuç arasında illiyet bağını aramak ve varsa kusur derecesinin ceza sorumluluğuna etkisini belirlemek gerekmektedir. 
Bu nedenle; ceza sorumluluğunun belirlenmesi açısından unsurların varlığını ortaya koyabilmek için yapılacak irdelemede yargıya yol gösterecek tıbbi durumun bilimsel açıklamasını yapabilmek için, bu aşamada irdelenmesi ve cevaplandırılması gereken sorular şu şekildedir;

- Dr. ... tarafindan uygulanan tedavi nedir ve tıbbi standartlara uygun mudur?

- Hastanın ayağını kaybetmesi sonucunu doğuran süreç nasıl gelişmiş ve seyretmiştir?

- Bu sürece belli noktalarda müdahale edilseydi hastanın bacağının kurtarılması mümkün olur muydu?

Hasta yaşadığı travmadan üç gün sonra başvurduğu acil servis hekimi tarafından muayene edilmiş, grafileri istenmiş, Ortopedi ve Travmatoloji konsültasyonu ile Op. Dr. ... tarafından görülmesi sağlanmıştır.

Op. Dr. ... tarafindan hastaya uzun bacak ateli mi yoksa kısa bacak ateli mi uygulandığı hususu tartışma konusu olmuştur; ancak Op. Dr. ..., tıbbi kayıtlara sekreterlik tarafından yapılan yanlışlık ile metatarsal kemik kırı̆ıı bulunduğu ve uzun-kol bacak alçı olduğu yazılmasına rağmen, kırık olmadığı ve hastaya kısa bacak ateli uyguladığını belirtmektedir.

Hastaya ait filmler incelendiğinde hastada kırık bulunmadığı anlaşılmakta olup, bu yöndeki acil muayene kaydı da dikkate alındığında; kırık olmayan, ezilme tarzındaki yaralanmalarda sirküler alçı değil, alçı atel uygulaması yapıldığından, hastaya uygulanan atelin "kısa bacak ateli" olduğu da tıbben anlaşılmaktadır.

Bu nedenle hastaya yapılan ilk müdahalenin tıbbi standartlara uygun, hasta yararına yapılan bir işlem olduğu görülmektedir.

Hasta, travmadan yani ayağına kütük düşsmesinden üç gün sonra hastaneye başvurmuştur. Bu gecikmenin neden kaynaklandığı tarafımızca anlaşılamamıştır.

Yine hasta ...'de ayağında morarma, şişlik, soğuma gibi bulgular olmadan ağrı şikayeti ile Dr. ...'ya başvurduğunda, ayağına debridman yapılıp hastadan yeniden film tetkiki istenmiş ancak hasta ilgili tetkiki yaptırmamıştır.

Ertesi gün Dr....'ya başvurduğunda ise ayağında farkIı bulgular tespit edilmiş ve hasta ... Üniversitesi Sağlık Uygulama ve Araştırma Merkezine sevk edilmiştir.

Hastanın acile ve ortopedi-travmatoloji kliniğine müracaatında hiçbir şekilde diyabet hastalığı öyküsünden bahsedilmediği görülmektedir. Üç gün önce travma anamnezi ile müracaat eden hasta, şeker hastası olduğunu belirtmediğinden, rutin olarak şeker hastası olup olmadığının sorgulanmamış olması veya dahiliye konsültasyonu istenmesi standart bir işlem olmadığından, eksiklik olarak değerlendirilmesi doğru bir yaklaşım değildir.
Nitekim, tıbbi kayıtlar incelendiğinde, hastada nekroz geliş̧mesi üzerine sevk edildiği ... Üniversitesi Sağlık Uygulama ve Araştırma Merkezi Plastik ve Rekonstrüktif Cerrahi Kliniğinde yapılan tetkikler ile kontrolsüz diyabet hastası olduğunun ortaya çıktığı anlaşılmaktadır.

Ayrıca, Adli Tıp Kurumu raporunda belirtildiği gibi kontrolsüz diyabeti olan kişilerde uygun takip ve tedaviye rağmen amputasyon oranının yüksek olduğunun tıbben de bilindiği görüşü yerinde bir tespittir:
“... ancak, mevcut olguda kontrolsüz DM hastalığı bulunduğu, söz konusu hastalıkta yara iyileşmesi- nin güçlüğ̈nün göz önüne alınmasının gerekli ol- duğu, kan şekeri kontrolü amacıyla iç hastalıkları konsültasyonu yapılabileceği ...”
“... travma esnasında meydana gelen cildin hasarlı bölgesinde enfeksiyonu önlemek maksadıyla alçıya kapak açılıp kısa aralıklarla pansuman yapılması- nın gerekli olduğu, bununla birlikte ilgili hekimin bunlara dikkat etmediğinin anlaşıldığı ..."

görüşleri yukarıda belirttiğimiz hususlar ile doğru değerlendirilmediği kanaatindeyiz.

Çünkü; hastanın diyabet hastalığı hakkında kendisinin de bilgisi olmadığı gibi hekimlere iletildiği yönünde bir belge de bulunmamaktadır. Hekimin kişide diyabet bulunup bulunmadığını anlaması, tespit etmesi gerektiği yönünde de tıbbi standart uygulama mevcut değildir. Ancak hastada klinik belirtilerin (çok su içme, idrara çıkma, ağız kuruluğu vb.) olması halinde araştırma yapması gerekir ki bunu gösteren klinik bir bulgu da yoktur.

Hastaya yapılan alçı, yumuşak doku travması nedeni ile standart olarak yapılan alçı atel uygulamasıdır. Hastaya sirküler alçı yapılma ihtimali de olmadığından, alçıdan kapak açılıp yara kontrolü yapılması yönünde bir işlem/uygulama da söz konusu değildir.

Bu bağlamda, Dr. ...'nın kusurlu eylemi olup olmadığı hususunun, hastaya uygulanan işlemin yani atelin ne olduğuna kesin olarak karar verilmesi yanında, hastanın travmadan üç gün sonra hastaneye başvurması, süreç içinde kontrol muayenelerine gelip gelmediği hususlarının değerlendirilmesi gerekir. Nitekim bu hususlar, illiyet bağının varlığı, var olduğu kabul edilmesi halinde de illiyet bağının kesilmesi ya da kusurluluk oranı açısından önem arz etmektedir.

Açıkladığımız nedenlerle tarafımıza sunulan belge ve tıbbi kayıtların incelenmesinden Dr. ...'nın şüpheden uzak kusurlu bir eyleminin bulunduğu yönünde kesin bir kanaate varılamayacağını belirtmek isteriz. 


\section{Sonuç}

Hasta ...'nın sağ bacağının kaybedilmesi ile Dr. ... tarafından sunulan tıbbi işlemlerde illiyet bağı olup olmadığı, Dr. ...'nın eylemlerinin kusurlu kabul edilip edilemeyeceği hususları, tarafımıza verilen dosyadaki tıbbi bilgi ve belgeler, Sağlık Hukuku Kurulumuzca değerlendirilmiştir.

- Hastanın travmadan üç gün sonra hastaneye başvurması, başvurusunda şeker hastalığı öyküsüne değinmemesi yanında hastada kırık olmaması sebebiyle hekim tarafından belirtildiği gibi kısa atel uygulaması yapıldığının kabulü gerektiği,

- Kapak açılmasını gerektiren sirküler alçı yapılmadığından, enfeksiyon kontrolü için alçıya kapak açma gibi bir uygulamanın tıbbi standartlarda bulunmadığı, zaten alçı atel uygulamasının doğasında yara ve dolaşım kontrolünün var olduğu,

- Crush (ezilme) yaralanmalarında, kontrolsüz diyabeti olan kişilerde uygun tedavi uygulansa da takip ve tedaviye rağmen amputasyon oranının yüksek olduğu,

dikkate alındığında;

- Ceza hukukunda önemli unsurlardan olan uygun illiyet bağının somut olayda varlığından bahsedilemeyeceği, kontrolsüz bir diyabet hastasında ağır bir yumuşak doku travmasının hastanın kaderini belirlediği ve bu nedenle geçirilen travma sonucu üç gün gecikme ile gelen olguda uygulanan tedavi ile ortaya çıkan sonuç arasında bir illiyet bağı kurulamayacağı, kanaatimizi, takdiri ilgili makama ait olmak üzere altı sayfadan oluşan işbu “Bilimsel Görüş”ü Türk Ortopedi ve Travmatoloji Birliği Derneği Sağlık Hukuku Kurulu olarak saygı ile sunarı.

\section{TOTBiD Sağlık Hukuku Kurulu}

Başkan Üye Üye Üye

\section{KAYNAKLAR}

1. BILIRKIȘiLIK KANUNU. Kanun Numarası: 6754 Kabul Tarihi: 3/11/2016 Yayımlandığı Resmî Gazete: Tarih: 24/11/2016 Sayı: 29898 Yayımlandığı Düstur: Tertip: 5 Cilt: 58. https:// mevzuat.gov.tr/MevzuatMetin/1.5.6754.pdf

2. TÜRK CEZA KANUNU Madde 276. Kanun Numarası: 5237 Kabul Tarihi: 26/9/2004 Yayımlandığı Resmi Gazete: Tarih: 12/10/2004 Sayı: 25611 Yayımlandığı Düstur: Tertip: 5 Cilt: 43. https://bilirkisilik.adalet.gov.tr/dokumanlar/ddmenukanunlar/ T\%C3\%BCrk\%20Ceza\%20Kanunu.pdf

3. Erdoğan E, Toraman B. Bilirkişilik Temel Eğitimi, Kaynak Kitabı. Editör: Canbolat T. Ankara: T.C. Adalet Bakanlığı, Bilirkişilik Daire Başkanlığı; 2017. Erişim: https://bilirkisilik. adalet.gov.tr/dokumanlar/bilirkisiliksempozyumkitaplari/ temelegitimkaynak.pdf

4. Bilirkişilik Temel Eğitimi, Katılımcı El Kitabı. Ankara: T.C. Adalet Bakanlığı, Bilirkişilik Daire Başkanlığı; 2017. Erişim: https://bilirkisilik.adalet.gov.tr/dokumanlar/ bilirkisiliksempozyumkitaplari/katilimcielkitabi.pdf 